\title{
The Entrepreneurship Development Program with the PALS Approach to Create Entrepreneurs at State Polytechnic of Batam, Indonesia
}

\author{
Shinta Wahyu Hati ${ }^{1 *}$, Rahmat Hidayat ${ }^{1}$, Hendra Gunawan ${ }^{1}$, Danar Irianto ${ }^{1}$ \\ ${ }^{1}$ Departement of Business Manajement, Politeknik Negeri Batam, Indonesia \\ ${ }^{*}$ Corresponding author. E-mail: shinta@ polibatam.ac.id
}

\begin{abstract}
In 2020, the State Polytechnic of Batam gained the third opportunity for the Community-Service program scheme of the Ministry of Research and Technology in the Entrepreneurship Development Program (EDP). The aim of this program was to create independent entrepreneurs based on technopreneurs. This program aimed to provide business development for tenants so that they are ready and independent in entrepreneurship, developing entrepreneurship based on knowledge and technology. The implementation of this program began with socialization, recruitment, and selection of prospective tenants. The method of implementing the program used the empowerment of entrepreneurial potential tenants, namely PALS (Participatory Action Learning System) to form a participatory learning interaction system. This program activity was carried out in early 2020 before the decision from the national government regarding the Covid-19 pandemic was made and this activity was also undertaken during the Covid-19 pandemic. Many of these entrepreneurship development program activities were carried out by implementing health protocols in order to prevent the spread of Covid-19. The results of the entrepreneurship development program found 44 tenants who had participated in the coaching, then a second selection was carried out to obtain 25 tenants. The Entrepreneurship Development Program Team conducted a third stage selection to get tenants who were further fostered until the end of the year, namely 10 tenants.
\end{abstract}

Keywords: Entrepreneurship Development Program, PALS, Tenant, Science and technology

\section{INTRODUCTION}

State Polytechnic of Batam has a commitment to develop entrepreneurship to play a role in realizing the independence of the nation. The direction of entrepreneurial development at State Polytechnic of Batam is technopreneur. The strategy for this achievement is through an incubation program, namely an Entrepreneurship Development Program (EDP). The entrepreneurship program at Batam State Polytechnic is part of entrepreneurship education which concerns on fostering and developing the business of students and alumnus of the Batam State Polytechnic.

The education of entrepreneurship in a tertiary institution is related to building the entrepreneurial character, an entrepreneurial mindset, and entrepreneurial behavior that is always creative and innovative, creates added-value or good values, utilizes opportunities, and is brave to take the risks. In facing the challenges of a highly competitive future, entrepreneurial behavior is needed for all occupations or professions [1].

The Entrepreneurship Development Program at State Polytechnic of Batam is a program with the aim of producing new independent entrepreneurs based on science and technology. This program is integrated with the research and community-service center program through the study center $\&$ the applied expertise group, besides this program is integrated with the section of student and alumni. The State Polytechnic of Batam receives a program scheme through a community-service scheme competition from the Indonesia Ministry of Research and technology / the National Research and Innovation Agency.

The development of this program involves the Study Center and the Expertise Group and is applied in business coaching and mentoring. Meanwhile, the tenants' input and development is coordinated under the student and alumniaffairs division. In the first and second years, this program has produced new entrepreneurs. In addition, the entrepreneurship development program has had an impact on improving and understanding tenants in developing their businesses. This program has provided an increase in the understanding and ability of tenants [2].

The implementation of this program in the third year is generally the same as it is in the following year. The process of selection for developing prospective entrepreneurs, namely the prospective tenants who are fostered, is carried 
out in stages starting from socialization and recruitment, selection, technical guidance, and business coaching through business guidance and assistance. Tenant is a person or group of people (maximum 3 people) who build a new start-up business, based on the technology that undergoes an incubation [3].

Tenant is an entrepreneur who must be able to discover the opportunities. It is expected that tenants who have been fostered, will play a role and contribute to improve the economy of Indonesia. There are functions and roles of entrepreneurship that can be seen through two approaches, namely micro and macro terms. In Micro term, Entrepreneurship has two roles, namely as an innovator and a planner. Meanwhile, while in macro term, the role of entrepreneurship is to create prosperity, equal distribution of wealth, and job opportunities which function as an engine of economic growth in a country [4].

The implementation of Entrepreneurship Development Program in the third year adopts the approach from 2018 to 2019, namely the PALS approach. The PALS (Participatory Action Learning System) approach is an approach in order to empower the entrepreneurial potential of students and alumni using the PALS (Participatory Action Learning System) method [5]. The benefit of the PALS approach to this program is being able to encourage the assisted-tenants to be able to apply business management. Entrepreneurship Development Program must include the ability to be creative and innovative, be observant in seeing opportunities, and always be open to change and challenges [6].

The research problem of this community-service is how to implement the Entrepreneurship Development Program (EDP) with PALS approach to produce / create entrepreneurs at Batam State Polytechnic.

\section{METHOD}

The EDP approach method in the context of empowering the entrepreneurship potential of student uses the PALS (Participatory Action Learning System) method. The basic principle of PALS method is the involvement of tenants in the active learning process of participants in entrepreneurship programs. The PALS method concerns on the transformation of existing activities to bring about changes towards improving the condition of student entrepreneurship through: 1) The entrepreneurial awareness phase; 2) The capaciting phase and the entrepreneurship capacity scaffolding; 3 ) The institutionalization phase of a new business as a new entrepreneur [5] [7] [8] [10]. The method of operating PALS in the Entrepreneurship Development Program at Batam State Polytechnic followed the principle of "learning by doing", in which it invites the student business tenants to pay attention, study, try to design and carry out / run the production, participate in handling the marketing, and perform the evaluation of all activities that have been carried out [9]. The expectation of using this method is that the participants or tenants can change their mindset and permeate the design process and business model, making product and service designs, production, and marketing. As the result, it will be easy to adopt the things that have been experienced.

The implementation of the basis of science and technology in this entrepreneurship program is the knowledge and skills that are needed by the individual to become an entrepreneur [11], which are:

1. Technical skill, covers the written and oral communication, technological skills, technical management, and organizing skills.

2. Business management skills, covers the planning, decision making, marketing, and accounting.

3. Personal entrepreneurial skills, includes inner-control, risk-taking, and innovation.

The abilities and skills that must be possessed by entrepreneurs as the participants of entrpreneurship program are given in the forms of intrapreneurship, rules and incubation processes and resources, training, mentoring, coaching, and network availability.

\section{FINDINGS AND DISCUSSIONS}

\subsection{Recruitment Patterns}

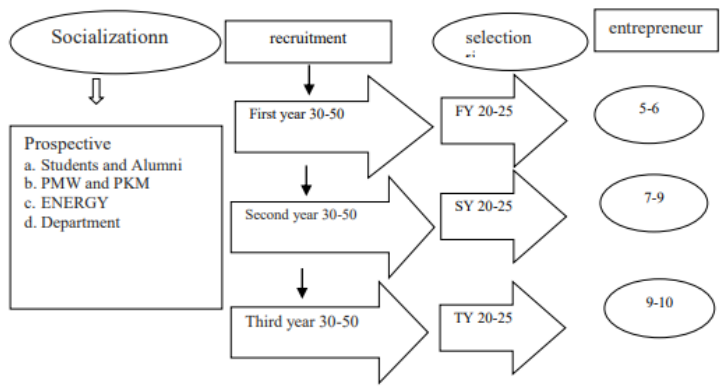

Figure 1 The Pattern of EDP at Batam State Polytechnic

We adopted ways of obtaining tenants such as the implementation of Entrpreneurship Development Program or EDP in 2018 and 2019. The selection process for prospective EDP participants at Batam State Polytechnic was carried out in stages namely as follows: 1) Socialiation to Management and Heads of Departement. The socialization was also held for student and alumni forums who were interested in developing a business. The recruitment socialization was carried out through electronic media, namely www.polibatam.ac.id and learning.polibatam.ac.id. 2). The next stage was conducting the selection on applicants for EDP [5].

\subsection{The Approach of PALS}

\subsubsection{The Phase of Awareness}

The entrepreneurship program in this phase aims to form and develop the attitudes and behaviors of "entrepreneurs", who are able to create innovation, and be proactive in facing environmental developments. The technical forms of 
training applied are classical method, case studies, discussions, and simulations. Technical activities have been carried out in the form of entrepreneurial technical guidance. In this phase, a learning study is carried out in the form of visitation to small, micro, small businesses so that tenants can learn to understand the MSME business processes and how to manage the business. Technical guidance activities are implemented before the pandemic and also during the pandemic period. Activities that have been carried out during the pandemic comply with health protocols to prevent the spread of Covid-19.

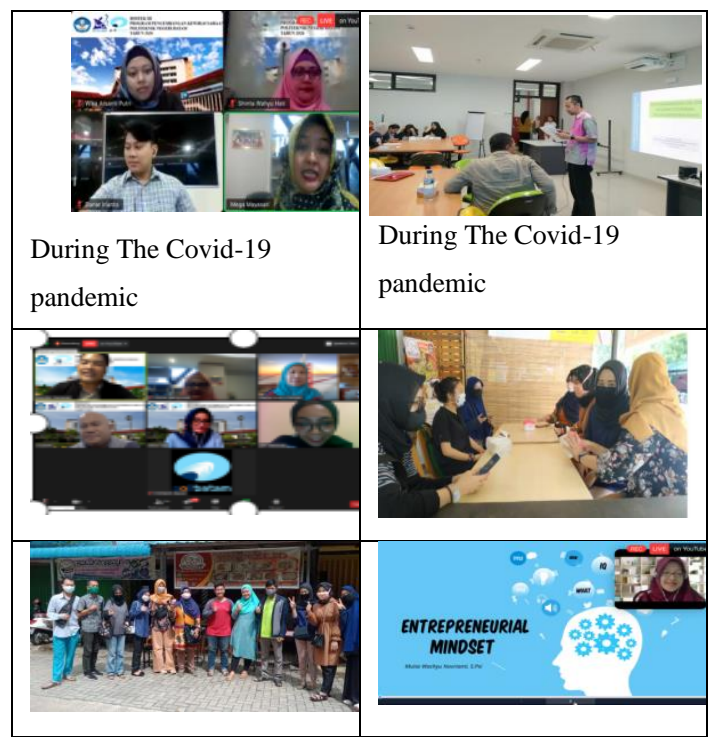

Figure 2 The Phase of Awareness

\subsubsection{The Phase of Capaciting and Scaffolding}

In this phase, the capacity-building method is applied to develop skills and capabilities of tenants to become entrepreneurs. In general, capacity building is the process or activity of improving the ability of a person, group, organization, or system to achieve better goals or performance. This phase aims to assist and guide the process of compiling management and production, solving problems faced by tenants in connection with their business. The character of the assistance is consulting business assistance and business guidance which is carried out continuously by upholding the principles of entrepreneurial management.

In this business consulting activity, we assist the tenants in analyzing the opportunities and potential of the market, mentoring in making business feasibility based on supply and demand, as well as helping to assist in business management. In this phase, tenants are given the opportunity and supported to participate in product exhibitions and involve them to enter the business community so that they can maintain and motivate themselves to continue to be enthusiastic in continuing their business. In this phase, the program team continues to make efforts to introduce and promote tenants' products through productive business development activities.

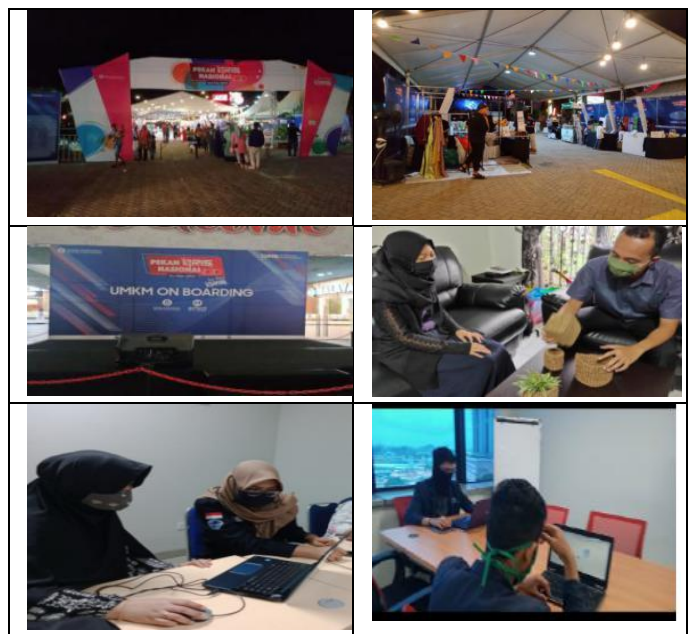

Figure 3 The Phase of Capaciting \& Scaffolding

\subsubsection{The Phase of Institutionalization}

In this phase, the EDP team conducts and creates a collaborative network with stakeholders. In the implementation, the program team of entrepreneurship development connects and brings together the tenants with associations or business communities. There is a difference in this year from the previous year, in which in this year due to the COVID-19 pandemic, the EDP team included the tenants in webinars held by the business community or association held by the community. In addition, the tenants also met online with participants who incidentally are small entrepreneurs so that through this forum, the tenants can usually establish business networks. In addition to being met with the business community, the tenants also met the small-business office to obtain the information about Micro, Small and Medium Enterprises (MSME) program during the pandemic as well as the ways to being fostered by the Cooperatives and Small and Medium Enterprises Office of Batam.

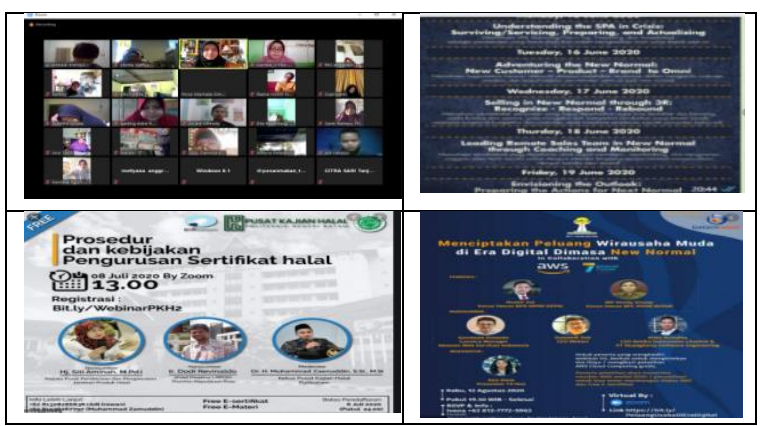

Figure 4 The Phase of Institutionalization

\subsection{Tenants were Selected in the First-Stage}

\subsubsection{Types of Gender}

The results of the data consisting of 44 tenants show that $52 \%$ was Male and $48 \%$ was Female. 


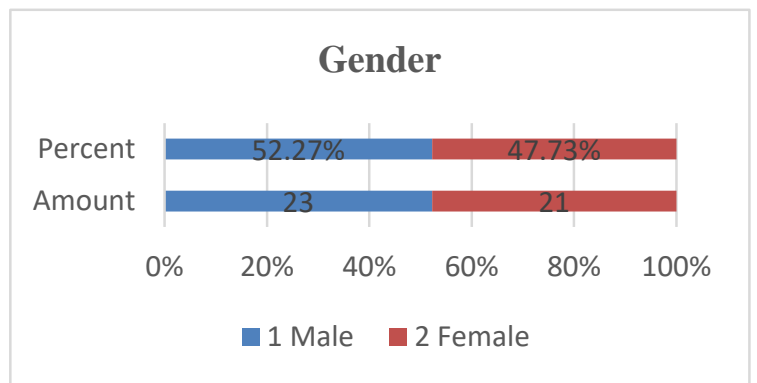

Figure 5 Types of Gender among 44 Tenants

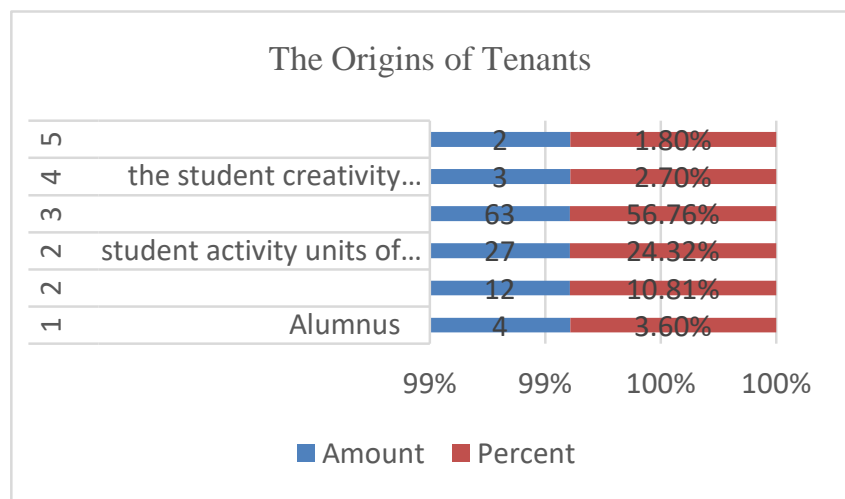

Figure 6 The Origins of Tenants

The results of the data indicate that the origin of tenants from the course curriculum was $56.76 \%$, from the student activity units of Entrepreneur Generation (Energy) and Students Association was $24.32 \%$, from the student creativity program was $2.70 \%$, and from the entrepreneurial student program was $1.80 \%$. Meanwhile, from the ordinary student, there was $14.41 \%$. and the last, there was $3.60 \%$ of alumni. The results of these tenants were the results of overall tenants, either individually or in groups.

\subsubsection{The Origins Department of Tenants}

As the origin department of tenants, from the major of Business Management was $63.96 \%$, from the major of Informatics Engineering was $19.82 \%$, from the major of Mechanical Engineering was 5.41\%, and from the major of Electrical Engineering was $10.81 \%$.

The Origins Department of tenans

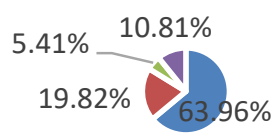

$$
\begin{aligned}
& \text { - } 1 \text { Manajemen Bisnis - } 2 \text { Teknik Informatika } \\
& \text { - } 3 \text { teknik Mesin }=4 \text { Teknik elektronika }
\end{aligned}
$$

Figure 7 The Origin Departement of Tenants

\subsubsection{Cluster Type of Business for Tenants in Stage 1}

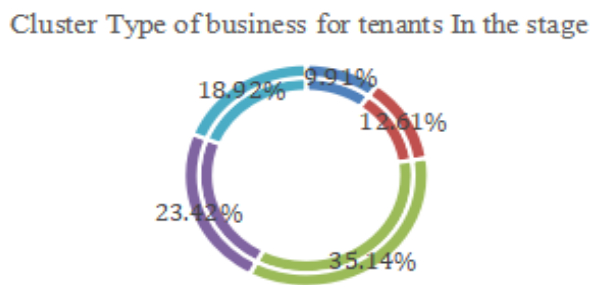

Figure 8 The Cluster Type of Business for Tenants in Stage 1

The average type of tenants' business was Information Technology (9.91\%), Service (18.92\%), Manufacturing $(12.61 \%)$, Culinary $(35.12 \%)$, and Trading $(23.42 \%)$. The tenants cluster shown were tenants per type of business, namely 44 tenants.

\subsubsection{The Need of Tenants to Join the Program}

The Need of Tenants to Join the Program

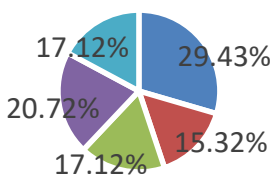

$$
\begin{aligned}
& \text { - } 1 \text { Marketing } \\
& \text { - } 2 \text { the support of business community } \\
& \text { - } 3 \text { feasibility study business } \\
& \text { - } 4 \text { business guidance } \\
& \text { - } 5 \text { financial }
\end{aligned}
$$

Figure 9 The Need of Tenants to Join the Program

Figure 8 shows the results of identification of 44 selected tenants in the first stage, in which the tenants' needs to take part in the Entrepreneurship Development Program were Marketing (29.43\%), The Support of Business Community (15.32\%), Having the Willingness to Make Business Financial Reports $(17.12 \%)$, Having the Willingness to Make a Business Feasibility Study (17.12\%), and Having the Willingness to Get Business Guidance (20.72\%).

\subsection{The Selected Tenants Continue to the Second-Stage}

The EDP team conducted the second-stage of selection to determine the 25 selected tenants to continue to be fostered and mentored. 


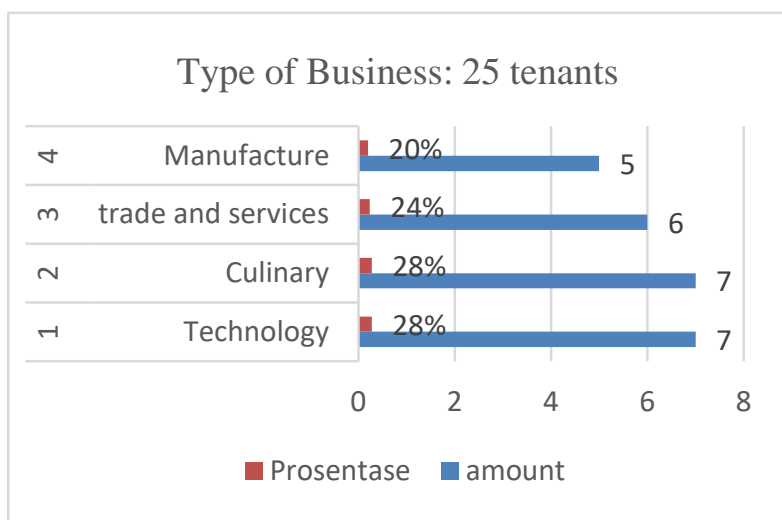

Figure 10 Type of Business: 25 Tenants

The criteria for selecting tenants were seen and identified from the output of business performance and activity following a series of entrepreneurial development programs. In the second-stage of selection, we carried out an assessment selection with the first criteria, namely the output of the progress of tenants' business performance, namely by identifying the performance of the application of science and technology in the progress of marketing \& sales activities, Business Model Canvas (BMC), recording \& managing business finances, compiling a business feasibility study, product development, and using the information technology in entrepreneurship.

The criteria of assessment for the second selection in the second-stage was tenants following the guidance, consultation and business assistance, and were actively participating in webinars with business associations / communities. The third selection assessment criteria in the second-stage was to identify motivation, persistence, enthusiasm for entrepreneurship, and the potential for the development of the following business.

\subsection{The Selected Tenants Continue to the Third- Stage}

Table 1 The Selected Tenants Continued in the Third-Stage

\begin{tabular}{|c|c|c|c|}
\hline Num & Business & Tenants & $\begin{array}{c}\text { Cluster Type } \\
\text { of Business }\end{array}$ \\
\hline 1 & Daily Hijab & Anisa Rahim & Trade \\
\hline 2 & Atleast Studio & $\begin{array}{l}\text { Rebby Michal } \\
\text { Lumangkun }\end{array}$ & Technology \\
\hline 3 & $\begin{array}{c}\text { Ngap Ngap Sweet } \\
\text { Corn }\end{array}$ & Afrizon & Culinary \\
\hline 4 & Holla Dimsum & Putri Zaenal & Culinary \\
\hline 5 & $\begin{array}{c}\text { Pasar kaget online } \\
\text { murah }\end{array}$ & Asep & Trade \\
\hline 6 & $\begin{array}{c}\text { Database of } \\
\text { Business }\end{array}$ & Moch Bagus & Technology \\
\hline
\end{tabular}

\begin{tabular}{|c|c|c|c|}
\hline 7 & Gimbab Juseyo & Wahyu & Culinary \\
\hline 8 & $\begin{array}{c}\text { Kinda Motion } \\
\text { Collective }\end{array}$ & $\begin{array}{c}\text { Riza Gilang } \\
\text { Darmawan }\end{array}$ & Technology \\
\hline 9 & Biles Kite & Mateus & Trade \\
\hline 10 & Coco Vase & Goyi Putri & Manufacturing \\
\hline
\end{tabular}

The origins Department of tenants: 10 tenants

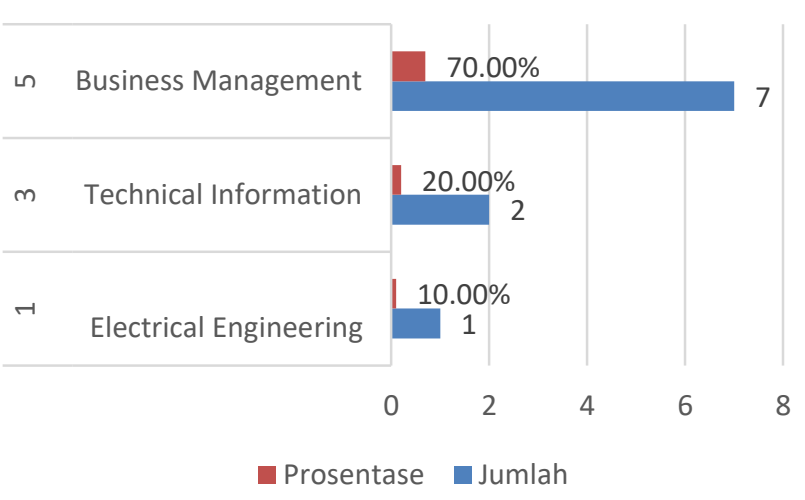

Figure 11 The Origin Department of Tenants: 10 Tenants

The results of the selection in the third-stage were 10 people. This selection was in the final stage, whereas the EDP team has selected 25 tenants into 10 tenants only. The criteria for selecting the 10 tenants were: 1 ) Sincerity and commitment to continue the business; 2) Conveying the business progress and efforts that have been made to develop their business; 3 ) Communicative and being active in following the business guidance; 4) Marketing and promotion; and 5) There is potential effort to run the business. A total of 10 (ten) tenants were selected as a result of the achievements in the third-year program, in which those ten tenants were mentored and assisted in managing their businesses.

The ten tenants were also included in webinar activities held by the association to gain the insight and share it with other MSMEs. This mentoring also involved the practitioners and lecturers from the Study Center \& Applied Expertise Group at Batam State Polytechnic to support the business guidance and mentoring.

Table 1 and Figure 9 show that the profiles of 10 tenants have been identified as follows: 1) One tenant in information technology with a percentage of $10 \% ; 2$ ) Two tenants in multimedia services with a percentage of $20 \% ; 3$ ) One tenant in manufacturing businesses with a percentage of $10 \%$; 4) Three tenants in trading business with a percentage of $30 \%$; and 5) Three tenants in culinary business with a percentage of 30\%. Figure 10 shows that the profiles of 10 tenants who came from the students and alumni were identified as 7 tenants from Business Management major with a percentage of $70 \%$, from Informatics Engineering major was $20 \%$, and from 
Electronic Engineering majors was only 1 tenant with a percentage of $10 \%$.

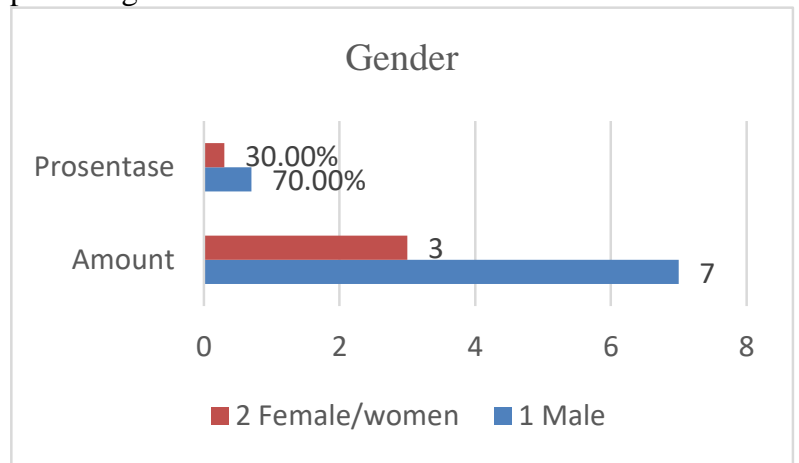

Figure 12 Types of Gender - 10 Tenants

Figure 11 indicates that among the 10 tenants, the total of women was only 3 persons with a percentage of $30 \%$, whereas this number was very small compared to last year (2019). The number of male tenants in 2020 was 7 persons with a percentage of $70 \%$. The types of tenants' business were services and multimedia. The first was Atleast Studio, which was engaged in the photography business, while the Kinda Motion business was engaged in the Motion Graphic animation business. The number of culinary business tenants was 3 (three) persons, in which the first was Gimbab Juseyo, a type of Korean meal, the second was a culinary business with the name of Ngap-ngap sweet corn, which is processed sweet corn, and the third was the culinary business of Holla Dimsum, which is a traditional Chinese food in the form of processed-food made from chicken and shrimp.

There was only 1 (one) business / tenant in the field of information technology, namely the Database of Business. This application is used for MSMEs. In manufacturing business, there was only 1 (one) tenant, namely Coco Vase, of which the product is a flower vase and flower pot made of coconut fibers with a unique design.

\section{CONCLUSION}

The results of the PALS approach that had been carried out were, the first, in the awareness phase, the activities for tenants were Technical Guidance for Entrepreneurship Training and learning studies or visitation to MSMEs. Capaciting \& Scaffolding Activities are in the form of business guidance, consultation, business assistance and marketing. Activities in the institutionalization phase included bringing together the communities / business associations through online webinars. The results of the first-stage selection process obtained 44 tenants, the second-stage selection process obtained 25 tenants, and the third-stage selection process obtained 10 tenants, who were fostered until the end of 2020, in order to be ready to be independent in entrepreneurial business.

\section{ACKNOWLEDGMENT}

We would like to thank the Indonesia Ministry of Research and Technology / National Research and Innovation Agency for providing the assistance for entrepreneurship development at State Polytechnic of Batam. We also thank to the State Polytechnic of Batam that has provided the required support for the implementation of Entrepreneurship Development Program activities.

\section{REFERENCES}

[1] Murfaizal. Y . Perilaku Technopreneur Mahasiswa Teknik Informatika Tinjauan pada Self-Sufficiency. Jurnal Fokus Bisnis, Volume 14, No 02, bulan Desember, 2014.

[2] Pajarianto. H. Adiguna., Ukkas., Priadi. Program Pengembangan Kewirausahan Di Perguruan Tinggi .SELAPARANG. Jurnal Pengabdian Masyarakat Berkemajuan.Volume 3, Nomor 1, November 2019. pISSN: 2614-5251, e-ISSN: 2614-526X.

[3] Pedoman inkubasi Bisnis Teknologi tahun 2017

[4] Suryana, Kewirausahaan Pedoman Praktis: Kiat dan Proses Menuju. Sukses, Edisi Ketiga, Penerbit Salemba, Jakarta. 2006.

[5] Hati. SW. Hidayat., R. Kartikaningdiyah., Gunawan. Technopreneur based Entrepreneurship Development Program As An Effort to Realize The Nationality Of Nationa In Politeknik Negeri Batam. Journal of Entrepreneurship, Business and Economics 6(2), 101-114, ISSN: 2345-4695 2018.

[6] Saragih., Intan. Membangun Usaha Kreatif Inovatif dan Bermanfaat Melalui penerapan Kewirausahaan Sosial. Jurnal kewirausahaan Volume 3 No. 2 Desember, ISSN : 2301-6264, 2017.

[7] Sitepul., Br Srinathasya. Analisis Program Entrepreneur Enabler Dengan Metode participatory ActionLearning System.Jurnal Bakti Masyarakat Indonesia ISSN 2620-7710 (Versi Cetak) Vol. 1, No. 2, November.ISSN 2621-0398, 2018.

[8] Sulistiyowati, W., AgustiniI., Fitiryah., H. Peningkatan Kapasitas Entrepreneurship Melalui Pelatihandan Magang Bagai tenant di Universitas Muhammadiyah Sidoarjo., Jurnal Pengabdian Pada Masyarakat Volume 1 No.1 Desember., age 1-5 PISSN: 2540-8739 || E-ISSN: 2540-8747, 2016. 
[9] Hackathorn, J. et.al. Learning by Doing: An

Empirical Study of Active Teaching Techniques. The

Journal of Effective Teaching, Vol. 11, No. 2, 40-54,

2011.

[10] Shodikin, Sutardi., Muhajir, Sumarno W. K., Iptek Bagi Kewirausahaan di Univeristas Islam Darul Ulum. Prosiding SENASIF-Seminar nasional Informatika, ISSN : 2597 - 4696, 2017.

[11] Abdullah, Sahadah., Osman Mohd, MH., Alias. RA. Framework for Technology Entrepreneur Development the International Journal of Knowledge Culture \& Change Management, Volume 8 Number 4, ISSN: 1447-9524, 2008. 